\title{
REAKTUALISASI GAMELAN KRUMPYUNG BERSAMA MGMP SENI BUDAYA KABUPATEN PURBALINGGA
}

\author{
Darno \\ Jurusan Karawitan \\ Fakultas Seni Pertunjukan ISI Surakarta \\ Email: darnokartawi@yahoo.id \\ Muriah Budiarti \\ Jurusan Karawitan \\ Fakultas Seni Pertunjukan ISI Surakarta \\ Email:muriah@isi-ska.ac.id
}

\begin{abstract}
Abstrak
Program Pengabdian Kepada Masyarakat (PKM) ini bertujuan untuk mengembangkan model pembelajaran praktek berbasis kompetensi yang berorientasi produktif dalam pembelajaran praktek bagi para guru seni di daerah. Ada dua target capaian pada program ini adalah meningkatkan kemampuan praktek musik tradisi bagi para guru seni, dan memahamkan prinsip-prinsip dasar penyusunan karya musik baru dari sumber musik daerah. Hasil kegiatan ini menunjukkan bahwa (1) model pembelajaran dapat meningkatkan kompetensi guru yang berorientasi produktif; (2) model pembelajaran tersebut efektif dapat meningkatkan kemampuan guru pada pembelajaran praktek; (3) model pembelajaran tersebut dapat menciptakan iklim belajar yang memposisikan peserta didik sebagaicentre learning dengan segala aktivitas yang dilakukannya. Metode yang digunakan adalah ceramah, demonstrasi, partisipasi, dan diskusi. Metode ini mendorong dan membangkitkan keberanian belajar dan bekerja yang didasari komitmen yang tinggi dan berdisiplin, meningkatkan kecepatan belajar, motivasi belajar, semangat belajar, kerja sama kelompok, kreatifitas, dan inovasi.
\end{abstract}

Kata kunci : pembelajaran praktek, reaktualisasi, penyusunan musik inovasi tradisi.

\begin{abstract}
This Community Service Program (PKM) aims to develop competency-based practice learning models that are productively oriented in practical learning for art teachers in the regions. There are two targets in this program to improve the ability to practice traditional music for art teachers, and to understand the basic principles of composing new music from local music sources. The results of this activity show that (1) the learning model can improve the competency of teachers who are productive-oriented; (2) the learning model can effectively improve the ability of teachers in practical learning; (3) the learning model can create a learning climate that positions students as learning centers with all the activities they do. The methods used are lectures, demonstrations, participation, and discussion. This method encourages and inspires courage to learn and work based on high commitment and discipline, increase the speed of learning, motivation to learn, enthusiasm for learning, group cooperation, creativity, and innovation.
\end{abstract}

Keywords: practical learning, re-actualization, compilation of musical innovations in tradition 


\section{Abdi Seni Jurnal Pengabdian Kepada Masyarakat}

\section{PENDAHULUAN}

Purbalingga merupakan salah satu daerah kabupaten di wilayah karesidenan Banyumas, dikenal sebagai salah satu kantong budaya subkultur dari kebudayaan Jawa yang memiliki aneka banyak ragam jenis kesenian. Kesenian Banyumas merupakan representasi dari karakteristik dan spirit bagi kehidupan masyarakatnya yang berakar dari pola kehidupan tradisional agraris. Sebagai bentuk kebudayaan yang tumbuh secara grassroot dari komunitas wong cilik, kesenian Banyumas dijiwai oleh semangat kebersamaan. Semua itu telah menjadi bagian tidak terpisahkan dari masyarakatnya yang secara turun-temurun tumbuh dan berkembang menjadi refleksi akan nilai-nilai kebersamaan yang secara simbolis juga tercermin dalam pertunjukan kesenian tradisionalnya.

Kesenian Banyumas dengan segala sifatnya, tumbuh,dan berkembang sejalan dengan peradaban Jawa Kuna. Budaya Banyumas juga diperkaya dengan masuknya gaya budaya Mataram (YogyaSolo) dan budaya Sunda (Pasundan/ Priangan). Semua itu telah menjadi bagian tidak terpisahkan dari masyarakatnya yang secara turun-temurun tumbuh dan berkembang menjadi refleksi akan nilainilai kehidupan yang cablaka, terbuka, dan apa adanya. Secara simbolis sifat-sifat tersebut tercermin dalam karakteristik kesenian tradisionalnya termasuk salah satunya pada musik bambu Krumpyung yang ada di Purbalingga.

Berdasarkan informasi dari Bapak Sulemi selaku pimpinan kelompok kesenian Krumpyung Sri Rahayu, ia menyampaikan bahwa pada awalnya musik Krumpyung hanya ada di Kecamatan Somagede - Kabupaten Banyumas yang dipimpinan oleh Bapak Rasadi Kresek. Setelah sebagian pemain meninggal, kemudian kesenian ini dibawa oleh salah satu pemainnya bernama Kasman ke Desa Langgar, Kecamatan Karangmoncol, Kabupaten Purbalingga, hingga saat ini. Bersama keluarganya yang terdiri dari kakak kandung kakakipar, paman, dan adik-adiknya, Kasman kemudian membentuk pelatihan secara rutin pada malam hari setelah shalat
Isya. Pada awalnya Kasman hanya ingin mengisi waktu luang dan menghibur diri. Kemudian, rasa cintanya terhadap kesenian Krumpyung menumbuhkan cita-cita yang mulia, yakni untuk menularkan ilmu dan keahlianya memainkan alat musik Krumpyung kepada saudara-saudaranya, sebagai upaya pelestarian kesenian tradisional musik bambu.

Kesenian Krumpyung merupakan kesatuan antara musik dengan lengger, yang oleh masyarakatnya sering disebut dengan kesenian Lengger Krumpyung. Walaupun kesenian Lengger Krumpyung berada di wilayah kebudayaan Banyumas, namun ia memiliki karakter estetika yang berbeda dengan jenis-jenis kesenian yang ada di Banyumas. Kesenian Krumpyung memiliki karakterisitik lebih kompleks yang banyak diwarnai oleh sajian musik tradisional gaya wetanan (Surakarta/Jogjakarta). Pada pertunjukan Lengger Krumpyung sering menyajikan gending-gending Surakarta seperti dalam bentuk lancaran, ketawang, ladrang dan jineman. Dengan banyaknya sajian gending-gending gaya wetanan pada pertunjukan Lengger Krumpyung maka tidak mustahil jika kemudian berpengaruh terhadap garapan sajian gending-gending lain termasuk dari gaya Banyumas itu sendiri dan gaya-gaya kulonan.

Lengger Krumpyung merupakan perwujudan nyata dari sebuah pertemuan tiga gaya musikalitas yang ada di Jawa. Pertemuan tiga gaya musikalitas telah dilebur jadi satu yang kemudian merefleksi ke dalam dinamika pertunjukan Lengger Krumpyung yang kadang berkesan lembut, keras, lucu, gecul, kasar dan gayeng. Penggambaran kesan-kesan tersebut sering terungkap melalui berbagai idiom garap seperti vokal, gending, tabuhan instrumen, teks cakepan, percakapan, dan juga terdapat pada gerak-gerak Tari Lengger. Interaksi sajian gending-gending musik Krumpyung dengan lengger menjadi gaya tersendiri dalam pertunjukan kesenian rakyat Banyumas. Bahkan ada beberapa tokoh seniman Banyumas seperti Rasito, Yusmanto, dan Kendar yang menyatakan bahwa musik Krumpyung adalah percampuran keseluruhan musik 
bambu yang ada di Banyumas yang diolah menjadi sebuah estetika lokal yang khas, unik, kompleks, dan rumit. Estetika lokal yang khas pada sajian musik Krumpyung tampak pada jalinan pola yang diadopsi dari permainan musik-musik yang lain seperti bongkel, gandalia, buncis, calung, dan gamelan ageng gaya wetanan. Satu kasus yang dimaksud sebagai bentuk adopsi pola tabuhan dari gamelan ageng gaya wetanan yaitu terdapatnya bentuk pola imbal instrumen Krumpyung penitir yang dipinjam dari pola imbal bonang barung dan bonang penerus. Kemudian pola-pola adopsi yang lain, misalnya terdapatnya pola melodi instrumen Krumpyung tengahan dari tabuhan musik bongkel dan gandalia. Pola imbal menjadi sangat dominan dalam sajian musik Krumpyung yang di dalamnya memiliki berbagai ragam bentuk, yakni imbal yang diadopsi dari bonang gamelang ageng, gambang calung, dan musik buncis.

Kesenian pada suatu daerah tertentu yang kemudian disebut sebagai kesenian daerah selalu sejalan dengan perkembangan pola pikir masyarakat pendukungnya. Kesenian daerah dan/ atau kesenian tradisional pada suatu daerah tertentu sebagian besar memiliki sifat yang terbuka, adaptif, dan fleksibel berjalan beriringan saling menginspirasi, saling mempengaruhi satu sama lain, seperti sifat-sifat manusia yang hidup dalammasyarakatnya. Demikian juga dengan sifat kesenian Banyumas yang hidup di tengah-tengah masyarakatnya yang diapit oleh kompleksitas kehidupan kesenian lain, maka tidak mustahil jika kesenian yang ada di daerah Banyumas kemudian satu sama lain memiliki kesamaan karakter. Kesenian Krumpyung sebagai salah satu jenis seni musik daerah dalam kenyataannya telah menunjukan sifatnya sebagai kesenian yang terbuka dan mampu beradaptasi dengan berbagai ragam jenis kesenian lain, baik yang berada di dalam maupun di luar lokus budayanya.

Berdasarkan sifatnya masing-masing, setidaknya ada enam jenis musik bambu di Karesidenan Banyumas yang pernah berjaya sebagai musik tradisional kerakyatan masyarakat yaitu ; bongkel, gandalia, buncis, krumpyung, calung, dan kentongan. Dari keenam jenis musik bambu tersebut empat di antaranya (bongkel, gandalia, buncis, dan krumpyung) memiliki kesamaan dalam cara memainkan yakni dengan teknik digoyang, digetar atau di-orog. Kemudian dua jenis musik bambu yang lain (calung dan kentongan) memiliki teknik berbeda, yaitu dengan cara dipukul (ditabuh) dengan menggunakan alat bantu lain yang disebut tabuh.

Musik bambu Banyumas di dalamnya terdapat banyak kemiripan baik secara bentuk visual maupun teknik menyajikannya, yang masing-masing memiliki karakter musikalitas yang berbeda-beda namun dalam spirit yang sama yakni kerakyatan. Perbedaan karakteristik musikalitas dari masingmasing jenis musik bambu tersebut dipengaruhi oleh dua hal, yakni faktor jenis lagu yang disajikan dan fungsi musik itu sendiri. Dari empat jenis musik bambu Banyumas yang dimainkan dengan teknik digoyang/ orog secara spesifik dibedakan oleh jumlah instrumen pada setiap perangkatnya yang kemudian berpengaruh secara musikal terhadap sajian instrumentasi repertoar lagunya. Karena memiliki kekhasan yang spesifik itulah maka musik Krumpyung menjadi unik. Unik jika dilihat dari sisi bentuk visual dan penyajiannya, dan juga unik jika dirasakan keindahan bunyinya.

Keunikan dan kekhasan musik Krumpyung terlihat dalam beberapa aspek, antara lain ; aspek teknik penyajian dengan cara di-orog (digetar), penyajian garap musikalitas, memiliki karakter warna bunyi yang nyaring dan tajam. Bentuk dari sajian garap musikalitasnya benar-benar dihiasi oleh nilai estetika yang sangat lokal, harmonis, kompleks, dan dinamis, sehingga membuat kebanyakan pemain pemula merasa kesulitan disaat memainkannya untuk mencapai tingkatan esetetika yang ideal. Musik Krumpyung memiliki teknik dan penggarapan instrumen lebih sulit dan kompleks yang berbeda dengan empat jenis musik bambu yang ada di Banyumas raya yakni bongkel, gandalia, buncis, dan calung. Kerumitan dalam penyajian musik Krumpyung setidaknya memerlukan empat aspek yang harus dikuasai yakni : 


\section{Abdi Seni Jurnal Pengabdian Kepada Masyarakat}

1. Membuat jalinan pola antar isntrumen untuk mencapai rasa musikal yang menyatu dan/atau senyawa, memerlukan pelatihan yang khusus.

2. Untuk menyatukan rasa dalam membentuk jalinan pola dan/ atau cengkok pada instrumen yang berpasangan, dibutuhkan pertemuan yang intens.

3. Dibutuhkan kesabaran, kepekaan, dan ketaatan yang tinggi terhadap aturan-aturan permainan teknik produksi bunyi, karena untuk mendapat hasil bunyi yang baik harus mampu mengelola peran jari-jari tangan yang fungsinya untuk mengatur getaran masing-masing bilah instrumen.

4. Disaat menyajikan instrumen yang berpasangan masing-masing pemain harus saling memahami keinginan lawan bermain terutama jika sedang menyajikan gending-gending yang garapnya memiliki beragam pola dan gaya musikal.

Begitu kompleks dan rumitnya penyajian musik Krumpyung gaya Banyumas jika harus bertahan dengan ciri khasnya. Sedangkan dewasa ini keberadaan kesenian-kesenian daerah yang khas dan masih bertahan eksistensinya sudah jarang ditemui. Sebagian besar kondisi kesenian-kesenian daerah telah hilang identitas keunikan dan kekhasannya. Jika masih ada yang bertahan untuk eksis kebanyakan telah bercampur dengan jenis musik lain yang oleh masyarakat dianggapnya sebagai suatu bentuk kebaruan. Seperti yang disampaikan oleh Sukendar dan Sutomo, dua sosok pelaku seni di Banyumas yang menyatakan bahwa, kehadiran jenis musik lain seperti musik pop, campursari, dangdut, dan musik dari luar negeri di masyarakat saat ini telah menjadi tantangan berat bagi para pelaku seni tradisi yang ada di daerah. Hanya ada dua pilihan, jika mau bertahan untuk tetap eksis diminati oleh masyarakat maka harus berubah, namun jika tidak mau berubah maka harus berhenti atau mati (wawancara 18 Agustus 2019).

Kelompok musik Krumpyung yang ada dan bertahan hingga saat ini hanya tinggal satu, yaitu kelompok Sri Rahayu, di Desa Langgar, Kecamatan Karangmoncol, Kabupaten Purbalingga. Kelompok ini mampu bertahan hidup semata-mata karena untuk kebutuhan hiburan keluarga, beranggotakan sepuluh orang yang kesemuanya merupakan saudara kandung dengan usia rata-rata di atas 50 tahun. Sulemi sebagai ketua rombongan menyatakan bahwa sudah tidak ada lagi regenerasi pemain musik Krumpyung, dikerenakan tidak ada anak muda yang suka dengan kesenian tradisi yang rumit. Kebanyakan anak-anak muda hanya mau menjadi seniman yang bentuk musiknya kekinian, yang ramai dengan alat-alat modern yang relatif mudah dimainkan. Kelompok Sri Rahayu ada dan tetap bertahan karena raca cinta Pak Sulemi terhadap musik Krumpyung yang merupakan warisan dari pendahulunya. Pak Sulemi merupakan penyambung warisan musik Lengger Krumpyung yang sebelumnya pernah bergabung dengan kelompok Krumpyung dari Desa Kecitran, Kecamatan Somagede, Kabupaten Banyumas pimpinan Bapak Kasadi Kesod (wawancara 10 Maret 2019).

Sulemi menguasai semua instrumen musik Krumpyung setelah belajar secara langsung kepada Bapak Kasadi Kesod melalui cara mendengarkan dan menirukan. Ironisnya kesenian ini hanya tinggal satu grup dengan kondisi anggota yang sangat memprihatinkan. Sangat disayangkan jika lambat laun kesenian ini menjadi hilang terbawa mati oleh pelakunya. Berangkat darikondisi ini, maka penulis mencoba untuk menggali beberapa teknik sajian musik Krumpyung yang khas untuk diangkat dan dikembangkan menjadi karya musik baru. Beberapa teknik sajian yang dikembangkan dalam karya ini antara lain: teknik orogan, pola jalinan penerus, penuthuk dan penodhong dalam instrumen Krumpyung ke dalam ragam instrumen dan bentuk musikalitas baru.

Akibat perubahan zaman, kesenian tradisional yang mengandung nilai-nilai lokal sudah banyak yang ditinggalkan oleh para pelakunya. Sebagian besar para pelaku seni tradisional banyak yang berbelok orientasinya dari yang semula memiliki prinsip dan idialisme yang kokoh untuk mempertahankan nilai-nilai lokal, kemudian beralih menjadi pelaku seni yang berorientasi kepada hal- 
hal yang lebih menjanjikan untuk mengejar materi untuk memenuhi kebutuhan hidupnya. Dalamkondisi yang demikian maka banyak kesenian tradisional yang kemudian ditinggalkan oleh pelakunya, bahkan tidak sedikit yang menggunakan kesenian tradisional sebagai topengnya agar tetap dianggap sebagai pelestari budaya lokal. Pada realitanya dewasa ini banyak kesenian lokal di Banyumas seperti karawitan, lengger, ebeg, wayang, dan jenis kesenian lokal lainnya yang bergeser bahkan berubah dan bercampur menjadi kesenian "baru" yang tidak jelas nilai-nilai estetikanya.

Penulis merasa prihatin akan keberlangsungan kesenian-kesenian lokal yang ada di daerah, khususnya di wilayah Karesidenan Banyumas, jika kehidupanya hanya dipasrahkan dan dikendalikan oleh para pelaku seninya. Tidak mustahil jika sepuluh tahun kemudian musik-musik lokal gaya Banyumas berubah menjadi kesenian baru yang kehilangan ciri khasnya yang sebagai penanda identitas lokal Banyumas. Berangkat dari fenomena tersebut, dalam program PKM ini penulis berinisiatif untuk mengalihkan peran penyangga musik tradisional dari pelaku seni ke guru-guru seni yang terhimpun melalui MGMP Seni Budaya. Pekerjaan ini pasti sulit dan berat karena guru seni tidak hanya fokus pada bidang seni tertentu saja, namun setidaknya jika dapat ditangani dunia pendidikan, kesenian lokal bisa tersalurkan kepada generasi penerus (peserta didik) melalui mata pelajaran muatan lokal, baik dari aspek pengetahuan maupun ketrampilannya.

\section{Permasalahan Mitra}

Musyawarah Guru Mata Pelajaran (MGMP) Seni Budaya adalah tenaga profesional guru yang memiliki tugas dan keahlian sebagai guru seni. Berdasarkan Kurikulum Pendidikan Berbasis Kearifan Lokal, kearifan merupakan keunggulan nilai-nilai lokal yang dipandang sebagai penguatan dalam konteks global melalui bidang seni budaya. Masuknya muatan lokalke dalam kurikulum sekolah adalah sebuah harapan yang bermanfaat bagi pengembangan kompetensi peserta didik untuk dapat dimanfaatkan sebagai persaingan global.

Berdasarkan dari serangkaian hasil survei terhadap mitra organisasi MGMP Seni Budaya di Kabupaten Purbalingga, ditemukan berbagai permasalahan sebagai berikut :

1) Terbatasnya pemahaman guru-guru seni tentang sifat-sifat dan estetika kesenian lokal sehingga berdampak pada minat yang rendah terhadap rasa ingin tahu akan nilai-nilai yang ada dalam kesenian daerah.

2) Masih minimnya kemampuan guru seni terhadap bidang keahlian praktek musik tradisional khususnya musik bambu,

3) Masih kurangnya kesadaran sebagian besar guru seni untuk memperdalam kemampuannya dibidang keahlian musik bambu tradisional sebagai bekal proses pembelajaran materi seni musik.

4) Adanya kendala dengan tidak tersedianya sarana pembelajaran berupa instrumen musik bambu sebagai media belajar.

5) Sangat kurangnya wawasan dan apresiasi guru seni terhadap kesenian lokal, baik yang dalam bentuk tradisional maupun karya-karya baru, sehingga anak didik tidak mendapat informasi yang lengkap tentang kekayaan dan perkembangan budaya lokal.

6) Terbatasnya ruang fasilitasi guru dalam mengembangkan bidang ketrampilan dan pengetahuan kesenian daerah, sehingga di dalam pekerjaan pokoknya sebagai guru seni menjadi tidak meksimal terutama berkenaan dengan pemberian materi ajar kepada siswa yang kecenderungannya menjadi tidak berkualitas dan tidak menarik.

Berangkat dari permasalahan yang ada pada guru-guru seni di Kabupaten Purbalingga berkaitan dengan kemampuan penguasaan praktek penyajian musik tradisi dan penyususnan musik baru yang rata-rata berkemampuan kurang, maka dalam kerjasama ini dipandang perlu. Seorang guru seni perlu diberi bekal yang cukup untuk menguasai 
bidang keahlian praktek, agar dalam tugasnya sebagai pendidik/guru kelas dapat menghasilkan anak didik yang berkualitas. Kabupaten Purbalingga menyimpan dan memiliki kesenian lokal yang khas, unik, serta spesifik yakni musik bambu. Untuk mewujudkannya, program ini lebih difokuskan pada dua bentuk kegiatan, yaitu pelatihan karawitan tradisi gaya Banyumas gamelan calung dan pelatihan penyusunan musik baru bentuk pengembangan musik Krumpyung dengan idiommayoritas instrumen bambu.

\section{MATERI DAN METODE}

Berangkat dari permasalahan mendasar pada rata-rata guru seni khususnya di Kabupaten Purbalingga yang kurang bahkan mayoritas tidak memiliki kemampuan memainkan alat musik daerah, sebelum nantinya diberi strategi atau metode penyusunan karya musik baru, maka pada program PPM Karya Seni kali ini perlu terlebih dahulu diberi materi-materi pelatihan musik daerah. Mengingat program ini dikhususkan untuk guru-guru seni di Kabupaten wilayah sebaran budaya Banyumas, maka materi dasar kesenian daerahnya adalah gending-gending Banyumasan dan gamelan calung. Dengan alasan bahwa gamelan calung dikenal sebagai salah satu identitas budaya Banyumas, dengan tingkat kesulitan yang bervariasi, mulai dari tingkat dasar (pemula) hingga tingkat mahir.

Program kegiatan ini difokuskan pada pembentukan perilaku aktif dan kreatif bagi seluruh peserta pelatihan, yang berorientasi pada kemampuan individu seorang guru seni, agar mampu dan memahami prinsip-prinsip penggarapan musik daerah (gending tradisi Banyumasan) dan penyusunan musik baru dalam bentuk inovasi tradisi. Berangkat dari kebutuhan tersebut, maka diperlukan seperangkat metode yang tepat dan cepat bagi seorang guru untuk mampu menjadi pendidik yang profesional, cerdas, kreatif dan berwawasan luas, terutama berkenaan dengan pengetahuan musik daerah.
Dalam rangka proses pembelajaran praktek karawitan Banyumasan gamelan calung dan penerapan konsep reaktualisasi pada guru-guru seni diperlukan strategi pembelajaran. Djamarah dan Zain (1996:5-8) telah mengemukakan pendapatnya bahwa dalam proses belajar mengajar ada empat strategi dasar, yaitu:

1. Mengidentifikasi serta menetapkan spesifikasi dan kualifikasi perubahan tingkah laku dan kepribadian anak didik sebagaimana diharapkan.

2. Memilih teknik pendekatan belajar-mengajar yang dianggap paling tepat dan efektif untuk mencapai sasaran.

3. Memilih dan menetapkan prosedur, metode, dan teknik belajar mengajar yang dianggap paling tepat dan efektif.

4. Menerapkan norma-norma atau kriteria keberhasilan sehingga pengajar mempunyai pegangan yang dapat dijadikan ukuran untuk menilai keberhasilan tugas-tugas yang telah diberikan.

Metode yang digunakan dalam pelatihan ini adalah dengan cara Trainer Penciptaan. Dalam proses pembelajaran karawitan gaya Banyumasan, digunakan beberapa metode mengajar sesuai dengan tujuan instruksional khusus yang ingin dicapai. Di antara berbagai metode yang telah dipakai antara lain metode latihan, metode demonstratif, metode drill, metode tanya jawab, metode instruksional, dan lain-lain sesuai dengan situasi yang terjadi dalam proses pelatihan.

Materi pembelajaran awal, diberikan materi tutor menulis notasi balungan gendhing, kemudian peserta pelatihan diminta untuk mencatatnya. Setelah proses awal selesai dilaksanakan, selanjutnya tutor menerapkan metode demonstrasi dengan cara mendemonstrasikan teknik bermain instrumen-instrumen tertentu di dalam perangkat gamelan calung. Dengan cara ini peserta pelatihan akan segera berapresiasi dengan materi gendhing yang diberikan, termasuk teknik-teknik bermain 
instrumen musik yang terdapat dalam perangkat gamelan calung.

Tahap berikutnya peserta pelatihan diminta untuk berlatih secara kelompok. Tahap ini adalah tahap penggunaan metode latihan yang dilakukan oleh tutor dalam rangka proses pembelajaran. Ketujuh macam ricikan di dalam perangkat gamelan calung secara keseluruhan harus ditabuh oleh peserta pelatihan secara bergantian dengan cara membuat urutan sebagai berikut: 1. kendhang, 2. gambang barung, 3. gambang penerus, 4. dhendhem, 5. kenong, 6. gong, dan 7. vokal (sindhensenggak). Teknik perpindahan formasi menabuh adalah urut satu per satu, misalnya: mulai dari instrumen gong berpindah ke kenong, kemudian pindah lagi ke dhendhem, gambang penerus, gambang barung, kendhang dan berakhir pada vokal sindhen-senggak. Dengan demikian setiap kali peserta pelatihan selesai menyajikan vokal, maka ia akan mencermati seluruh sajian ricikan sambil mengevaluasi dirinya atas hasil praktek yang telah dilalui dalam putaran pergantian tabuh bersama.

Apabila untuk teknik-teknik tertentu peserta pelatihan dirasa ada kesulitan teknis, maka tutor akan menerapkan metode drill. Dalam hal ini peserta pelatihan diminta untuk melakukan praktek berulangulang pada teknik-teknik tertentu yang dianggap sulit dikuasai. Pada saat-saat tertentu tutor membuka forum bagi peserta pelatihan untuk menanyakan halhal yang kurang jelas sehingga tutor dapat menerangkan lebih terperincihingga akhirnya peserta pelatihan dapat segera menyerap materi secara tepat.

Model penyampaian yang digunakan dalam kegiatan penguatan keterampilan dasar musik tradisi gamelan calung ini adalah metode strategi instruksional yang berupa ceramah, diskusi, pelatihan, tugas apresiasi (mendengarkan) dan pengamatan langsung terhadap pertunjukan karawitan Banyumas di lapangan. Alokasi waktu untuk setiap kali pertemuan adalah satu jam tutor menyampaikan materi garap gending, dilanjutkan 5 jam berikutnya untuk pelatihan dan diskusi. Satu jam di akhir setiap tatap muka kegiatan digunakan peserta pelatihan untuk membuat rangkuman feed back guna mengukur dan mengevaluasi hasil pembelajaran, sekaligus untuk melihat sejauh mana tingkat penyerapan peserta pelatihan terhadap materi yang telah disampaikan.

\section{SOLUSI YANG DITAWARKAN}

Permasalahan mendasar yang sering dialami oleh para guru dalam mengajar adalah perencanaan dan kesiapan untuk mengelola pembelajaran agar tercapai kompetensi yang ditargetkan kepada siswa. Secara konseptual, kemungkinan pengembangan strategi pembelajaran dapat diakui sebagai salah satu sarana bagi dunia pendidikan untuk memberikan dan memperluas wawasan pembelajar tentang pengetahuan, keterampilan, dan nilai-nilai dasar lainnya agar mampu diimplemteasikan dalam kebiasaan saat bertindak dan berpikir. Proses pembelajaran musik tradisional di dunia pendidikan perlu dikembangkan secara kreatif untuk menciptakan konsep-konsep baru yang lebih komprehensif sekaligus kompetitif.

Seperti yang telah dilakukan oleh R. Mursid dalam bukunya berjudul "Pengembangan Model Pembelajaran Praktek Berbasis Kompetensi Berorientasi Produksi" yang menjelaskan bahwa dalam proses pembelajaran praktek di kelas, guru dapat melakukannya dengan menggunakan metode pembelajaran baru yang lebih fleksibel, dengan menempatkan anak didik sebagai subjek (StudentCentered Learning $=S C L$ ), dibandingkan sebagai objek pendidikan. Dalam penjelasan berikutnya ditegaskan bahwa konsep pendidikan juga perlu didesain untuk menumbuhkan semangat kewirausahaan dan peningkatan soft skills serta success skills sehingga lulusan perguruan tinggi mempunyai karakter percaya diri yang tinggi, memiliki kearifan terhadap nilai-nilai sosial dan kultural bangsa, kemandirian serta leadership yang kuat (HELTS, 2004: 22). Dengan demikian, dalam kegiatan pelatihan ini penulis berupaya mengembangkan model pembelajaran untuk mengembangkan kreativitas guru, terutama aspek 


\section{Abdi Seni Jurnal Pengabdian Kepada Masyarakat}

berfikir kreatif, inovatif, dan produktif, yang diharapkan mampu meningkatkan kualitas pembelajaran, sekaligus mampu meningkatkan kompetensi praktek para guru seni di bidang pendidikan khususnya mata pelajaran kesenian daerah.

Proses pembelajaran Lembaga Pendidikan Tenaga Kependidikan Pendidikan Teknologi Kejuruan (LPTK-PTK, 2003: 2) berorientasipada: (1) kegiatan pembelajaran perlu memperhatikan perbedaan kemampuan individu dan dapat mengembangkan bakat dan potensi peserta didik dalam bidang keahlian secara optimal(competency based learning); (2) kegiatan pembelajaran ditekankan pada pemberian pengalaman nyata dalam kehidupan sehari-hari sesuai dengan kebutuhan dunia kerja dan terkait dengan penerapan konsep, kaidah, dan prinsip disiplin ilmu yang dipelajari; (3) pembelajaran perlu diarahkan untuk mendorong peserta didik dapat mengkomunikasikan kreasi temuannya kepada masyarakat luas sehingga dapat mengembangkan empati dengan menyelaraskan pengetahuan yang dimiliki dengan tindakannya; dan (4) pembelajaran diarahkan untuk menciptakan iklim kompetisi sehingga dapat menghasilkan karya-karya yang inovatif dan produktif.

Metode pembelajaran dalam mencapai keahlian apapun tentu tujuannya sama yakni hasil yang berkualitas. Untuk mencapai hasil yang maksimal dalam pelatihan musik bambu gamelan calung dan penyusunan musik inovasi tradisi, tentu harus didukung dengan metode yang tepat, agar mencapai harapan yang ideal. Pemilihan metode dilakukan dengan mempertimbangkan situasi dan kesesuaian materipelatihan. Oleh karena materiyang disampikan berbeda antara kepada mahasiswa di kampus dengan guru-guru dengan tingkat kemampuan dasar yang berbeda-beda, maka metode baru sangat diperlukan. Terkait dengan pembelajaran ketrampilan gamelan calung karawitan tradisi gaya Banyumas dan penyusunan musik baru bentuk inovasi tradisi, maka tutor memilih metode sebagai berikut :
1. Metode ceramah, digunakan untuk menjelaskan garap musik tradisi gamelan calung gaya Banyumas secara umum, dan menjelaskan konsep penyusunan musik baru yang bersumber dari kesenian daerah Purbalingga, yaitu musik Krumpyung.

2. Metode demontrasi, adalah mempraktekkan prinsip-prinsip garap sajian instrumen gamelan calung berdasarkan pemahaman yang dijelaskan melalui metode ceramah.

3. Metode partisipasi, peran aktif para peserta menjadi sangat penting, karena dengan keikutsertaan dalam memperhatikan, serta menirukan pelatih saat memberi contoh, akan mempercepat daya tangkap serta kemampuan mempraktekan materi yang diberikan.

4. Metode diskusi, adalah salah satu langkah cepat untuk membantu daya nalar melalui tukar pikiran guna memperdalam pemahaman peserta pelatihan.

Walaupun telah merencanakan metodemetode yang sistematik, namun dalam pelaksanaan di lapangan dapat berubah secara tiba-tiba. Oleh sebab itu, tutor yang kreatif juga harus memiliki kiatkiat yang adaptif agar proses pembelajaran dalam segala situasi tetap mampu berjalan dengan baik dan lancar.

\section{TARGET LUARAN}

Dalam kegiatan ini penulis membuat target dan luaran kegiatan PKM bagi guru seni yang dapat dijelaskan melalui 4 (empat) aspek utama, yaitu :

1. Menghasilkan modul pembelajaran gending Banyumas gamelan calung serta penyusunan musik baru yang bersumber dari musik tradisional Purbalingga bernama Krumpyung.

2. Menciptakan karya musik bambu dengan kebaruan bersumber dari reaktualisasi musik Krumpyung, hasil kolaburasi berbagai jenis musik bambu Banyumas.

3. Menghasilkan artikel yang siap dimuat dalam jurnal ilmiah sebagai publikasi dan 
pertanggungjawaban kepada dunia seni umumnya, mitra kerja sama, dan lembaga ISI pada khususnya.

4. Dokumentasi audio visual pelaksanaan kegiatan pelatihan serta penyajian musik baru hasil karya peserta pelatihan.

\section{PELAKSANAAN PROGRAM}

\section{Jadwal Pelaksanaan}

Jadwal pelaksanaan program PKM ini merupakan hasil kesepakatan antar berbagai pihak yang disinergikan melalui musyawarah bersama MGMP Seni Budaya Kabupaten Purbalingga, Dinas Pendidikan Dan Kebudayaan Purbalingga, serta penanggungjawab tempat pelatihan gedung Maesa Jenar, pada hari Sabtu, tanggal 4 Mei 2019 di Purbalingga. Sejak ditentukannya jadwal kegiatan pelatihan dari bulan Mei hingga akhir Oktober 2019 secara umum terselenggara dengan lancar. Berikut ini jadwal pelaksanaan kegiatan program PKM "Reaktualisasi Musik Krumpyung bersama MGMP Seni Budaya Kabupaten Purbalingga" tahun 2019 :

1. Pertemuan pertama tanggal 15 Juni 2019, dengan materi saresehan yang berjudul "Kronologi Musik Bambu Banyumas", yang didahului penjelasan tentang program PKM dalam tema "Reaktualisasi Musik Krumpyung Kerja Sama dengan MGMP Seni Budaya" Kabupaten Purbalingga.

2. Pertemuan kedua tanggal 22 Juni 2019, adalah tahap pelatihan pertama dengan agenda memberikan materi dasar musik bambu Banyumas gamelan calung, tentang prinsipprinsip dasar penggarapan instrumen, serta pengenalan teknik-teknik yang diwadahi dalam pola-pola tabuhan dari tingkat yang paling sederhana.

3. Pertemuan ketiga tanggal 29 Juni 2019, mengulang materi yang sama pada pertemuan sebelumnya dengan tabuhan bersama secara bergantian.

4. Pertemuan keempat tanggal 6 Juli 2019, menerapkan pola-pola dasar tabuhan gamelan calung ke dalam sajian gending tradisi Banyumasan (Eling-Eling) irama 1 (lancar), yang dilanjutkan pengenalan vokal gending eling-eling dalam sajian irama 1 (lancar)

5. Pertemuan kelima tanggal 13 Juli 2019, pemberian materi tabuhan gamelan calung dalam sajian gending Eling-Eling irama ll (dados).

6. Pertemuan keenam tanggal 20 Juli 2019, mengulang materi tabuhan gemelan Calung dalam irama dados secara bergantian.

7. Pertemuan ketujuh tanggal 26-27 Juli 2019, pendalaman materi gending Eling-Eling dari irama lancar sampai irama dados, yang dilanjutkan pelatihan vokal gending Eling-Eling irama dados.

8. Pertemuan kedelapan tanggal 2 - 3 Agustus 2019, latihan pendalaman materi gending ElingEling dari irama lancar, irama dados, kembali irama lancar, hingga suwuk, evaluasi, dan peresentasi hasil pelatihan materi dasar penyajian gending Eling-Eling dalam gamelan calung.

9. Tanggal 10 Agustus 2019, pertemuan kesembilan, apresiasi musik Krumpyung dan kentongan secara langsung yang dipertunjukan oleh pelaku seni dari kelompok kesenian Krumpyung Sri Rahayu pimpinan Bapak Sulemi dan kelompok kentongan Dersanala pimpinan Bapak Sutomo Purbalingga. Dalam sesi ini seluruh peserta ditugaskan untuk mencermati aspek-aspek penyajian khususnya instrumen musik Krumpyung sebagai bahan kajian untuk dikembangkan ke dalam susunan musik baru dalam bentuk inovatif.

10. Pertemuan kesepuluh tanggal 7 September 2019, pemaparan konsep penyusunan karya musik baru yang bersumber dari musik tradisi. Pada sesi ini juga dilakukan praktek kerja eksplorasi instrumen dengan memberikan polapola tabuhan beberapa ricikan melalui prinsip transmedium dan pengembangan sumber tradisi dari musik Krumpyung. Prinsip transmedium dituangkan ke dalam beberapa ricikan antara 


\section{Abdi Seni Jurnal Pengabdian Kepada Masyarakat}

lain: kenthur, gambang calung, dan angklung jinjing.

11. Pertemuan kesebelas tanggal 14 September 2019, memberian pola-pola melodi untuk instrumen anglung gantung dan gambang Calung. Pada sesi ini dilanjutan proses penggabungan seluruh pola tabuhan, baik yang bersifat ritmik ataupun melodik.

12. Pertemuan keduabelas tanggal 21 September 2019, pelatihan materi vokal. Adapun vokal yang dipilih sebagai lagu utama dalam penyusunan karya ini adalah lagu Ayo Ngguyu laras pelog pathet nem, dan Jolio laras slendro pathet manyuro. Pada sesi ini juga diberikan materi baru yang digunakan sebagai awal penyajian musik yaitu intro atau pambuka. Untuk mengakhiripertemuan sesi ini peserta diuji coba untuk menggabungan semua unsur tabuhan ricikan dan vokal dari intro hingga selesai.

13. Tanggal 28 September 2019, pertemuan ketigabelas, latihan pendalaman materi dan pembenahan teknik-teknik tabuhan ricikan yang salah. Pembenahan teknik penyajian pada bagian sambung rapat dan dinamika sajian, terutama saat perubahan tempo dan permainan keras-lirih. Pembenahan teknik vokal yang terkait dengan pelarasan dan aksentuasi yang berkenaan dengan kekompakan ritme.

14. Tanggal 5 Oktober 2019, pertemuan keempatbelas, pendalam materi dengan menyajikan karya dari awal hingga akhir, dilanjutan pelatihan ekspresi dan pengaturan gerak tubuh untuk menghidupkan penyajian di pertunjukan.

15. Pertemuan kelimabelas tanggal 19 Oktober 2019, pendalaman materi, yakni materi tradisi dan karya baru untuk persiapan presentasi dan pendokumentasian hasil pelatihan, baik penyajian materi tradisi maupun karya baru.

16. Tanggal 26 Oktober 2019, presentasi dan pendokumentasian hasil pelatihan materi tradisi gending Eling-Eling Banyumasan dan karya baru "Reatualisasi Musik Krumpyung".

\section{Tahapan Pelaksanaan}

Melalui tahapan-tahapan penyelenggaraan program PPM yang telah berlangsung selama lima bulan sejak bulan Juni hingga Oktober 2019 telah berhasil menuntaskan duajenis kegiatan yang konkrit yaitu ; 1) peningkatan kemampuan keterampilan praktek bagi guru seni pada penyajian gendinggending tradisi gaya Banyumas dalam gamelan calung pada tingkat dasar (pemula), dan 2) pembekalan prinsip-prinsip dasar penyusunan karya musik baru yang bersumber dari musik daerah. Dua hal ini dirasa penting untuk dibentuk pada guru-guru seni di daerah, terutama berkenaan dengan visi misi pemerintah tentang peningkatan Sumber Daya Manusia (SDM) yang unggul untuk mencapai Indonesia Maju. Unggul dalam hal ini adalah berkaitan dengan kualitas guru seni yang memiliki kemampuan ilmu dan ketrampilan seni lokal yang memadai, sesuai dengan tuntutan zaman agar keutuhan dan keberagaman budaya Nusantara tetap terjaga.

Beberapa tahapan pelaksanaan kegiatan ini adalah berupa langkah-langkah yang mungkin dan bisa dilakukan oleh siapapun. Langkah-langkah tersebut telah disusun secara sistematis dan logis, sesuai dengan kaidah-kaidah akademik. Kiranya menjadi penting dalam dunia pendidikan diajarkan logika-logika kreatif kepada anak didik melalui dunia penciptaan seni musik. Dalam usaha untuk melancarkan target capaian hasil pelatihan program PKM karya seni, maka tahapan-tahapan kegiatannya telah dilakukan secara berjenjang dan terstruktur.

Langkah pertama adalah kegiatan saresehan/ diskusi dengan topik "Kronologi Musik Bambu Banyumas dan Ciri Khas Keunikan Estetika Lokal". Dalam tahapan ini capaiannya adalah membentuk rasa penasaran dan keingintahuan pada para guru tentang keunggulan secara estetika musikal, keunikan, dan ciri khas yang dimiliki oleh musik Krumpyung Purbalingga, sehingga kemudian memunculkan dorongan rasa ingin tahu yang kuat akan keunikan dan kekhasan esetetika lokal musik bambu Banyumas. 
Langkah kedua adalah apresiasi musik Krumpyung. Untuk mempengaruhi rasa menjadi ingin tahu, salah satu upayanya adalah mengapresiasi serta memberi contoh-contoh permainan musik Krumpyung mulai dariyang paling mudah/sederhana hingga yang paling rumit/sulit. Setelah mengapresiasi dan mencermati berbagai unsur sajian musikal musik Krumpyung, lalu diberitugas untuk mencatat aspekaspek sajian yang dapat ditangkap untuk kemudian dijadikan sumber penyusunan musik baru.

Langkah ketiga adalah pelatihan dasardasar musik tradisi gaya Banyumas pada gamelan calung. Beberapa alasan diberikannya pelatihan gamelan calung adalah, karena gamelan calung merupakan akumulasi (muara) dari seluruh permainan musik bambu yang ada di Banyumas. Dengan mempelajari gamelan calung, maka semua peserta akan dapat memahami aspek-aspek garap musik bambu dari segala teknik dan pola. Pada tahap ketiga ini semua peserta diperlakukan sama, yakni diberi pelatihan cara memainkan instrumen gamelan calung dengan teknik dan pola yang mudah dan sederhana. Dari pelatihan tahap ini akan terlihat kemampuan masing-masing peserta dan ketrampilan yang dimilikinya, sehingga akan memudahkan tutor untuk mengelompokkan kelas kemampuan untuk mengembangkan tahap berikutnya, yakni penyusunan karya baru bentuk inovasi tradisi.

Tahap keempat adalah kelanjutan level kemampuan teknik interaktif. Pada level ini peserta diberi pola-pola sajian intrumen yang beragam, yang disesuaikan berdasarkan kemampuan masingmasing peserta yang telah dilihat daripelatihan tahap sebelumnya. Bagi peserta yang dilihat memiliki kecepatan menirukan dan memainkan secara individu, akan diberi pola-pola sajian yang lebih sulit. Jika terlihat dari daya tangkap dan fleksibelitas tangan dalam memainkan instrumen ada yang secara visual terlihat rileks, maka pelatih akan memberikan teknik serta pola yang lebih dinamis. Begitu seterusnya pelatih memberikan rangsangan-rangsangan kognisi dan psikomotorik sehingga akan memudahkan untuk modal dasar dalam menyusun sebuah bentuk karya baru.
Tahap kelima adalah mengelompokan kemampuan peserta berdasarkan level masingmasing untuk dijadikan ukuran dalam menyusun karya. Pada tahap pengelompokan ini, pelatih akan memberikan materi-materi pola sajian instrumen, berdasarkan pada unsur-usur musikal yang kompleks dan/ atau beragam. Untuk mempermudah masing-masing pemain instrumen dalam menguasai pola sajian yang diberikan, juga dilakukan pelatihan secara parsial. Tahap ini adalah proses penggemblengan teknik dan hafalan setiap individu, sehingga jika masing-masing telah terlihat menguasai dengan terampil, maka akan dilanjutkan pada tahap berikutnya yakni penggabungan.

Tahap keenam adalah proses penggabungan unsur-unsur musikal dalam kerangka penyusunan musik baru. Dalam tahap ini semua peserta pelatihan dilatih dan dikondisikan terlebih dahulu untuk mengenal pola masing-masing pemain instrumen, untuk kemudian pelatih/ penyusun memahamkan kepada semua pemain instrumen akan pentingnya hubungan jalinan pola setiap pemain sehingga jika bermain dalam satu kerangka akan mengetahui efek masing-masing pola terhadap kesan musikalitas dalam sajian karya secara utuh.

Tahap ketujuh adalah proses pendalaman materi. Proses pendalaman materi dalam sebuah kerja penyusunan karya baru adalah bagian akhir dari keseluruhan proses yang lalui. Pada tahap ini penyusun/ pelatih akan mengontrol masing-masing permainan instrumen, sehingga jika terdapat kekurangan dalam mencapai kesan musikal yang dikehendaki maka dapat dilakukan evaluasi dan pembenahan-pembenahan secara mendalam.

Melalui pelatihan kreativitas penyusunan karya musik baru ini diharapkan akan menghasilkan tenaga-tenaga guru seni yang kreatif dan mumpuni. Dengan demikian, maka kekhawatiran akan punahnya keberlangsungan kesenian tradisional di wilayah Karesidenan Banyumas, khususnya Kabupaten Purbalingga, tidak akan terjadi lagi. Guru seni yang mumpuni dan mencintai kesenian tradisi lokalnya akan secara otomatis menjadi media transformasi keberlangsungan kesenian tradisi 


\section{Abdi Seni Jurnal Pengabdian Kepada Masyarakat}

kepada generasi muda yang dalam hal ini adalah anak didik.

Kegiatan pemberdayaan MGMP bertujuan memberi pembekalan kepada guru-guru seni baik dalam kemampuan praktek menyajikan musik bambu secara tradisional maupun dalam strategi penyusunan musik baru yang bersumber dari musik Krumpyung. Kegiatan ini berlangsung sekitar 6 (enam) bulan yang dimulai dari observasi, pembuatan proposal, kegiatan lapangan, hingga penyusunan laporan kegiatan. Kegiatan ini lebih mengutamakan pembentukan sikap kebersamaan, kedekatan secara emosional antara tutor, narasumber, dan peserta kegiatan, sehingga materi bisa terserap secara optimal tanpa ada yang merasa terpaksa dan dibebani dengan kegiatan tersebut. Narasumber dan tutor selalu bersikap terbuka untuk saling berbagi dan menerima semua ide-ide kreatif yang lahir dari peserta kegiatan, sehingga program initidak semata-mata mengutamakan hasil produk seni musik secara instan, namun lebih membentuk kesadaran semua peserta pelatihan akan pentingnya sebuah proses.

\section{KEBARUAN PROGRAM PKM}

Kegiatan PKM dalam tema "Reaktualisasi Gamelan Krumpyung” telah berhasil mendapatkan satu bentuk langkah baru dengan alur rangkaian kegiatan yang harus dilakukan untuk mencapai tingkat pemahaman dan kemampun guru seni sebagai penyusun karya baru yang bersumber dari potensi musik daerah. Kebaruan yang dimaksud yaitu membentuk kemampuan menyusun karya musik baru dari sumber musik bambu gamelan Krumpyung.

Kebaruan yang diterapkan dalam program ini adalah menemukan strategi-strategi untuk memahami cara-cara menyusun musik baru dalam bentuk inovasi tradisi secara mudah dan sistematis. Program PPM merupakan upaya nyata yang dapat secara langsung dirasakan dan dialami oleh masyarakat yang dalam hal ini guru-guru seni di Kabupaten Purbalingga. Berangkat dari kenyataan bahwa sebagian besar peserta kegiatan (guru seni) masih belum sepenuhnya menguasai hal ihwal yang berkenaan dengan perihal musik daerah, berkat program ini akhirnya mampu merubah secara cepat para guru seni untuk dapat memahami serta melakukan praktek musik tradisi, baik pada tingkat penyajian maupun penyusunan karya inovasi.

Musik tradisi merupakan obyek material yang ada di daerah-daerah, menjadi sebuah fenomena yang menarik untuk dijadikan sumber penciptaan karya baru dengan cara digali dan dikembangkan ke dalam bentuk yang lebih kekinian. Namun demikian akan mustahil mampu menyusun karya dengan hasil yang baik jika tidak dibekali terlebih dahulu kemampuan dasar musik tradisi yang memadai. Sebagai langkah awal sebelum diberikannya pelatihan penyusunan musik baru, maka dalam program ini diberikan dasar-dasar keterampilan musik bambu Banyumas. Karena dari sekian banyak jenis musik bambu Banyumas yang memiliki kompleksitas garap paling beragamadalah musik calung, maka terlebih dahulu guru-guru seni dibekali pelatihan untuk mampu dan memahami prinsip-prisip garap sajian gending-gending tradisi Banyumas pada gamelan calung. Bentuk-bentuk kebaruan yang telah dilakukan dalam proses pembelajaran keterampilan praktek musik tradisi gamelan calung dilakukan secara bertahap yang dimulai dari aspek-aspek musikalitas yang paling mendasar hingga yang bersifat pengembangan.

\section{Pelatihan Keterampilan Tingkat Dasar}

Pelatihan keterampilan dasar yang dimaksud adalah proses membentuk sikap seseorang yang dalam hal ini guru seni, untuk menguasai prinsip-prisip dasar memainkan alat-alat musik bambu tradisi dalam penyajian gending-gending tradisi gaya Banyumas. Mengingat banyaknya jenis musik bambu di Banyumas, maka sebagai stimulan pada program ini difokuskan pada salah satu instrumen bambu gamelan calung. Seperti yang telah dinyatakan oleh Yusmanto dalam sebuah penelitiannya yang berjudul "Kajian Musik Calung Sebagai Bentuk Identitas Budaya Banyumas", maka 
dalam konteks penguatan identitas budaya lokal seorang guru seni yang berada di lingkungan budaya Banyumas harus lebih memahami kaidah-kaidah estetika musik tradisinya. Dalam gamelan calung terdapat aspek-aspek garap musikal yang kompleks, khas, dan unik, karena memiliki ragam teknik dan pola sajian yang mencakup tiga gaya karawitan yaitu gaya kulonan (Pasundan), Banyumas, dan wetanan (Surakarta, Yogyakarta).

gamelan calung dalam satu perangkat memiliki tujuh ricikan/ instrumen yang terdiri dari : kendang, gambang barung, gambang penerus, dhendhem, kenong, gong dan vokal. Untuk membekali keterampilan guru seni agar setiap personal menguasai semua ricikan, maka dilakukan praktek menabuh bersama secara bergilir. Ada beberapa prioritas materi yang diberikan secara mendalam yaitu vokal, gambang, dan kendang, karena materi-materi tersebut merupakan bagian terpenting yang harus dikuasai dan dipahami sebagai sebuah esensi musikal yang menjadi penanda ciri khas sajian gending Banyumas dalam gamelan calung. Adapun ricikan yang lain seperti dhendhem, kenong dan gong sekalipun memiliki teknik yang khusus, namun tidak terdapat bentuk sajian yang rumit sehingga pada ricikan tersebut tidak dibutuhkan prioritas waktu yang lebih.

\section{a. Vokal}

Vokal dalam sajian gending-gending tradisi gaya Banyumas memiliki dua jenis yaitu jenis vokal sindhenan dan senggakan. Pada pelatihan keterampilan dasar diberikan materi-materi yang sifatnya fundamental, yakni berupa materi yang bisa mendasari prinsip-prinsip garap sajian vokal gaya Banyumas sebagai acuan garap gending-gending lain yang sejenis. Adapun materi vokal yang diberikan adalah bentuk sindhenan tunggal, koor, dan senggakan.

\section{b. Kendang}

Pada karawitan Banyumasan kendang merupakan ricikan yang sangat vital. Kendang di samping memiliki peran sebagai pengatur jalannya sajian gending juga memiliki fungsi sebagai pembentuk ciri khas karawitan gaya Banyumas. Pada pelatihan tingkat dasar, materi ricikan kendang diberikan beberapa teknik dan pola-pola yang diharapkan nantinya dapat membekali calon pengendang untuk mampu memahami dan mempraktekkan garap sajian gending-gending Banyumasan pada jenis yang paling populer. Dari jenis gending ini setidaknya akan mempermudah pengendang untuk cepat mampu beradaptasi dengan jenis gending yang bentuknya sepadan. Adapun materi yang diberikan pada pelatihan tingkat dasar ini ada dua jenis, yaitu jenis kendang gembyakan (kendang satu), dan kendang ketipungan (kendang dua). Untuk kendang gembyakan akan lebih banyak digunakan pada sajian gending irama 1 (lancar), sedangkan kendang ketipungan diterapkan pada sajian gending irama 11 (dados). Ada empat jenis materi kendang gembyakan pada irama 1 (lancar) yaitu pola kendangan baku, singgetan, peralihan, dan pola suwuk.

c. Gambang

Pada karawitan Banyumasan, gambang merupakan ricikan yang sangat unik. Selain memiliki karakteristik bunyi yang unik, gambang juga memiliki berbagai jenis pola yang dapat beradaptasi dengan berbagai ragam gaya karawitan di sekitarnya. Beberapa nama pola gambang yang telah dikenal oleh pengrawit Banyumas antara lain; pola imbal, pola gambangan, pola bukak-tutup, pola onelan, dan pola kentrungan. Sekalipun banyak kemiripan dengan bentuk pola sajian gambang yang ada di gaya karawitan Surakarta dan Sunda, namun secara teknik dan penyatuannya di dalam penyajian gending sangatlah berbeda. Gambang pada gamelan calung adalah instrumen yang bertugas sebagai pemicu lagu vokal, sehingga gambang menjadi satu kesatuan yang saling menguatkan dalam pembentuan suasana gending.

\section{d. Dhendhem}

Jika pada seperangkat gamelan ageng gaya Surakarta, terdapat ricikan balungan yang salah 


\section{Abdi Seni Jurnal Pengabdian Kepada Masyarakat}

satu tugasnya sebagai ricikan penyaji kerangka gending yang terdiri dari slentem, demung, saron barung dan peking, pada gamelan calung ricikan dhendhem-lah yang mewaliki empat jenis ricikan tersebut. Ricikan dhendhem dalam gamelan calung sekalipun tampak seperti menyajikan kerangka gending, namun dalam realitanya terdapat teknikteknik tabuhan yang merupakan bentuk penyatuan dari empat ricikan dalam gamelan ageng. Dalam tekniknya kadang tampak seperti demung/ slenthem, tetapi justru banyak teknik sajian yang digarap sama persis dengan teknik cacahan saron penerus.

\section{e. Kenong}

Ricikan kenong, walaupun nama ini sama persis dengan salah satu ricikan yang ada dalam perangkat gamelan ageng, namun ricikan kenong dalam gamelan calung sangatlah berbeda cara penyajiannya. Dalam gamelan calung, ricikan kenong selalu disatukan dengan ricikan kethuk, sehingga antara tabuhan kethuk dan kenong adalah bentuk kesatuan pola tabuhan yang tidak bisa dipisah. Ricikan kenong pada gamelan ageng dikategorikan sebagai ricikan struktural, karena pola tabuhan yang digunakan merupakan penentu bentuk gending. Berbeda dengan kenong pada gamelan calung, ia lebih banyak difungsikan sebagai ricikan penyeimbang ricikan gambang penerus, sehingga terdapat nama teknik yang sama yakni bukak-tutup. Dalam teknik tabuhan antara kenong dengan gambang penerus sering terjadi jalinan interaksi pola yang saling mengisi, sehingga jika salah satunya tidak bisa diajak berinteraksi, maka sajian gendingnya akan terasa pincang.

\section{Penyusunan Karya "Reaktualisasi Krumpyung"}

Raktualisasi dalam konteks ini adalah sebuah konsep atau gagasan penulis untuk berupaya menghadirkan kembali spirit dan nilai-nilai lokal dalam kesenian Krumpyung. Dalam Kamus Besar Bahasa Indonesia (KBBI) kata reaktualisasi artinya ; proses, dan perbuatan mengaktualisasikan kembali. Reaktualisasi dimaknai sebagai penyegaran dan pembaharuan kembali nilai-nilai yang ada dari kehidupan masyarakat yang dalamkonteks ini adalah musik bambu tradisional Purbalingga bernama Krumpyung. ${ }^{1}$ Konsep reaktualisasi yang diimplementasikan dalam program PPM Karya Seni kali ini adalah bentuk kegiatan berupa sebuah proses penyusunan musik baru yang bersumber dari musik Krumpyung di Kabupaten Purbalingga. Luaran yang dicapai dalam kegiatan adalah karya musik baru dalam bentuk inovasi musik bambu yang disusun berdasarkan langkah-langkah sistematik yang dilakukan melalui tahapan-tahapan sebagai berikut:

\section{A. Tahap Pra Penyusunan Karya}

\section{Reaktualisasi Gamelan Krumpyung}

Reaktualisasi Krumpyung adalah sebuah konsep karya musik baru yang mencoba mengangkat kembali materi-materi musikal dari gamelan Krumpyung ke dalam bentuk bangunan yang berbeda dari aslinya. Dalam konsep penyusunan karya ini penyusun menggunakan prinsip-prinsip penyusunan karya inovasi tradisi yang telah dikembangkan oleh I Wayan Sadra yakni prinsip "pertumbuhan" dan "transmedium" dalam sebuah modul kekaryaan kreatif mahasiswa yang berjudul "Eksplorasi Bunyi Gamelan Dalam Penciptaan Karya Musik" (54:2002).

a. Prinsip Pertumbuhan

Prinsip pertumbuhan yang dimaksud adalah tindakan kreatif dalam melakukan proses penyusunan bentuk musikal yang terinspirasi dari sumber-sumber tradisi yang dalam konteks ini adalah musik bambu tradisional Purbalingga bernama gamelan Krumpyung. Aspek-aspek musikal dari gamelan Krumpyung terlebih dulu diidentifikasi, dikelompokkan berdasarkan sifat masing-masing yang unik dan khas, untuk kemudian diolah kembali sesuai dengan daya interpretasi penyusun.

Dalam prinsip pertumbuhan, kerja penyusun mencoba untuk selalu melibatkan aspek afektif dan kognitifnya, sehingga langkah-langkah yang dilalui selalu dapat dijelaskan secara realistis dan sistematis. Contoh prinsip pertumbuhan yang telah dilakukan 
dalam karya reaktualisasi gamelan Krumpyung antara lain; penyusun mengambil pola tabuhan imbal instrumen angklung:

Angklung 1, $\frac{\cdot 2}{\cdot \frac{2}{2} \cdot \frac{5}{5} \cdot \frac{2}{2} \cdot \frac{5}{3}}$

Angklung 2, 3 • 6 . 3 . 6 .

Kemudian dikembangkan ke dalam tiga instrumen kenthur menjadi:

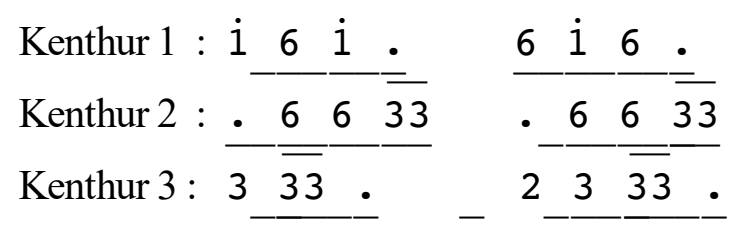

Perbedaan pola dan ritme dari angklung yang secara struktur berubah itulah yang kemudian disebut sebagai pertumbuhan. Prinsip yang dicapai dalam konsep pengembangan sumber adalah membuat semangat yang baru, namun masih dalam nuansa yang sama, yakni kesan unik dan khas.

\section{b. Prinsip Transmedium}

Prinsip transmedium adalah proses pemindahan pola tabuhan dari instrumen satu kepada instrumen yang lain, yang dalam hal ini adalah polapola tabuhan yang tersaji dalam instrumen gamelan Krumpyung ke instrumen bambu lainnya yang berbeda dengan kebiasaan dalam tradisinya. Beberapa contoh pola tabuhan yang dialihinstrumenkan antara lain dari instrumen angklung penitir ke instrumen angklung gantung, dari intrumen angklung penodong ke instrumen gambang calung, dari instrumen kendang ke instrumen drum-set. Berikut contoh prinsip transmedium dari angklung penodong ke gambang calung :

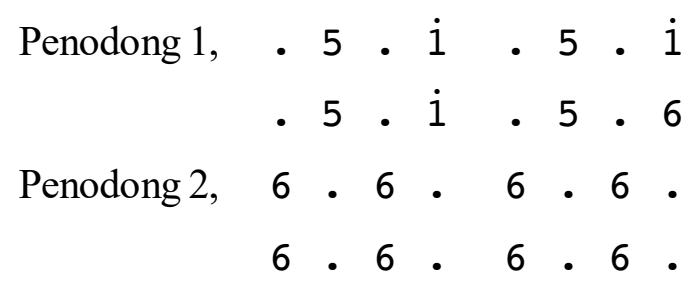

\section{menjadi}

Gambang 1,

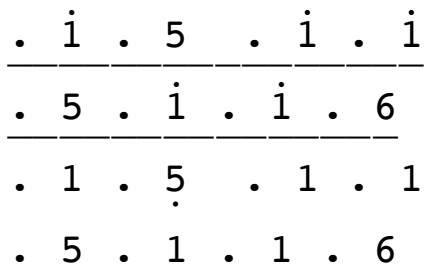

Gambang 2,

$\frac{6}{3 \cdot} \frac{3}{6} \cdot \frac{6}{6} \cdot \frac{6}{6} \div$
$6 \cdot 3 \cdot \frac{6}{6} \cdot \frac{6}{6}$
$3 \cdot 6 \cdot 6 \cdot 6$

Berdasarkan konsep dasar penyusunan karya baru yang bersumber dari potensi kesenian daerah, maka untuk mendapatkan sumber referensi yang tepat dan akurat, semua peserta pelatihan harus mengikuti langkah-langkah sebagai berikut :

1. Apresiasi

Berangkat dari tema reaktualisasi musik Krumpyung, maka bentuk kegiatan apresiasi difokuskan pada pertunjukan musik Krumpyung. Kegiatan apresiasi adalah langkah awal dalam pembentukan peserta pelatihan (guru-guru seni) agar mempunyai gambaran secara umum tentang musik Krumpyung. Dari kegiatan apresiasi, semua peserta diminta untuk mencatat dan mendokumentasikannya dengan alat rekam audio-video dengan tujuan agar bisa dicermati secara berulang-ulang untuk kemudian mampu me-review dalam bentuk deskripsi yang selanjutnya akan dijadikan sebagai bahan tindak lanjut untuk mengidentifikasi ciri khas sajian musik Krumpyung.

\section{Orientasi}

Orientasi dari karya "Reaktualisasi Krumpyung" merupakan jenis karya musik baru yang diangkat dari fenomena musikal, yaitu musik Krumpyung. Karya musik ini merupakan bentuk pengembangan dari beberapa unsur musikal yang ada pada sajian musik Krumpyung seperti teknik menabuh instrumen, pola ritme, pola imbal, dan pola jalinan yang dihasilkan dari seluruh ricikan dalam seperangkat musik Krumpyung. Konsep 


\section{Abdi Seni Jurnal Pengabdian Kepada Masyarakat}

reaktualisasi bertujuan untuk mengaktualkan dan menghadirkan kembali semangat dari suasana musik Krumpyung yang berbeda dari aslinya. Semangat baru dalam karya "Reaktualisasi Krumpyung" merupakan bentuk inovasi tradisi musik Krumpyung yang dipadukan dengan beberapa instrumen lain agar hasil akhirnya mampu mengaktualkan kembali unsurunsur mendasar pada sajian musik Krumpyung. Unsur-unsur mendasar dalam musik Krumpyung adalah bangunan gending yang terbentuk dari berbagai repertoar garap musikal yang tersaji dalam ricikan pokok yang disebut "angklung gantung". Ada tiga repertoar pola garap musikal yang diterapkan pada masing-masing bagian ricikan, yaitu ; (a) pola titiran, disajikan dengan ricikan angklung penitir bagian wilayah empat nada tertinggi, (6-1-2-3),(b) pola ngedhongi disajikan oleh ricikan penodhong bagian wilayah nada angklung terendah ( $3-5-6-1-2-3)$, dan (c), pola imbal, disajikan oleh ricikan angklung bagian tengah $(6-1-2-3-5-6-1-2-3-5-6)$ oleh dua orang. Repertoar garap-garap ini direinterpretasikan ke dalam instrumen lain menjadi bentuk jalinan yang lebih mudah dan dinamis. Dengan memindahkan media yang berbeda pada instrumen baru yang menggunakan teknik lebih mudah inilah yang kemudian mampu menghadirkan kembali semangat dan suasana musik Krumpyung ke dalam karya baru oleh pemain pada tingkat pemula.

\section{B. Tahap Penggarapan}

Pada tahap penggarapan ini merupakan bagian dari proses kerja penyusun dalam menemukan kerangka maupun garap karya, sehingga menjadi sebuah susunan atau bangunan musik inovasi "Reaktualisasi Krumpyung" yang sesuai dengan konsep yang dirancang. Berikut tahapantahapan penyusunan yang telah dilalui dalam proses penyusunan:

\section{Eksplorasi}

Karya musik ini dituangkan ke dalam instrumen bambu dengan memadukan berbagai jenis dan bentuk yang mayoritas terbuat dari bahan baku bambu. Instrumen-instrumen yang digunakan adalah; dua set angklung gantung, empat gambang calung, empat buah angklung jinjing, enam buah instrumen kenthur, dan dua set-drum mini.

Proses eksplorasi diawali dari pencarian teknik membunyikan instrumen dari berbagai jenis, yang dilanjutkan dengan pencarian pola-pola sajian untuk diinventarisir sebagai bank pola. Pola-pola sajian yang telah didapat kemudian ditentukan dan ditetapkan untuk dipertemukan dengan instrumen lain ke dalam frame tempo tertentu. Jika pertemuan pola-pola sajian antar instrumen telah dirasa menghasilkan kesan musikal yang diinginkan, kemudian disimpan dan dicatat sebagai bahan untuk dipertimbangkan dalam tahap penyusunan karya.

Proses eksplorasi kedua adalah pencarian materi garap vokal. Pada proses eksplorasi vokal lebih ditekankan pada materi-materi vokal yang sudah ada pada lagu-lagu daerah setempat, baik yang bersifat tradisional maupun populer. Ada dua jenis vokal yang dieksplorasi dalam karya ini, yaitu vokal melodi (lagu) dan vokal senggakan. Vokal lagu yang diambil dari lagu-lagu daerah antara lain lagu Jolio, Kaji-kaji, dan Ayo Ngguyu. Lagu Jolio dan Kaji-kaji merupakan lagu daerah Banyumas yang pernah dikenal pada masa kejayaan seni pertunjukan kerakyatan Banyumas seperti lengger, slawatan, gandalia dan ebeg. Pada karya ini sengaja di angkat dengan tujuan agar lagu-lagu daerah khas Banyumas yang berlaras slendro mampu hadir kembali dalam kemasan yang kekinian dan dinamis, sehingga generasi muda yang mayoritas kurang menyukai lagu-lagu daerah menjadi tertarik. Tiga jenis lagu ini masing-masing dielaborasi dengan instrumen musik bambu melalui pendekatan garap yang sederhana, nge-pop, sehingga mampu membangkitkan semangat baru, tanpa meninggalkan nuansa kedaerahannya. 


\section{Tahap Penyusunan}

Berdasarkan dari berbagai materi yang telah tentukan pada tahapan sebelumnya, langkah selanjutnya adalah tahap penyusunan karya. Sajian karya ini diawali dari intro drum-set dengan polapola yang diadopsi dari sekaran kendangan gaya Banyumas yang diambil sebagian dari bentuk aterater. Dari pola tersebut di-transmedium-kan ke instrumen drum-set dalam bentuk pola sebagai berikut:

Pola 1

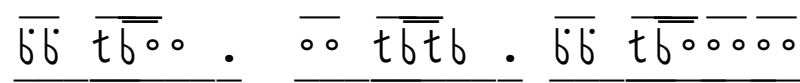
$\overline{. b} . \bar{b} . \overline{b P} t$.

Pola 2

$\overline{t l p} t \overline{t l p} t \overline{t l p} t \overline{b l} \overline{b l} \overline{t l p} t$ $\overline{t l p} t \overline{t l p} t \overline{b l} \overline{b l}$

$\overline{t P} \overline{b l} \cdot \bar{P} . \quad \overline{b d} d d d$

Pola drum-set dalam notasi tersebut disajikan secara besama-sama oleh dua pemain dalam tempo sedang yang bertujuan untuk memandu tempo sajian selanjutnya, serta memicu suasana sajian musikalitas selanjutnya agar kesan yang dicapai memiliki kesan ceria, dinamis, serta kerakyatan. Setelah dua kali intro drum disajikan kemudian masuk bagian pengantar lagu atau dalam karawitan Jawa disebut ompak. Berikut bentuk pola permainan instrumen dalam karya reaktualisasi Krumpyung :

1. Pola pokok/ dasar instrumen drum-set yang dimainkan secara intens

$$
\left[\begin{array}{llllllll}
\overline{. b} & \overline{p . p} & \overline{p P} & \overline{. P} & \rho & \overline{b b} & \overline{. b} & \mathrm{~B}
\end{array}\right]
$$

Pola pokok adalah pola tabuhan yang disajikan secara dominan baik pada bagian intro/ ompak maupun lagu. Jika terjadi adanya sajian yang berbeda pada bagian ompak ataupun lagu maka itu bersifat variasi-variasi individu yang biasa disajikan oleh pemain drum-set jika ia telah memiliki pengalaman yang cukup untuk berekspresi dengan berimprovisasi di atas panggung.

2. Pola permainan instrumen kenthur;

Kenthur 1 nada 2 - $3<$

$[\overline{.2} \quad \overline{3 \overline{33}} \div \overline{2} \overline{3 \overline{33}}]$

Kenthur 2 nada $6-3<\left[\begin{array}{lllll}\overline{6} & \overline{33} & \overline{6} & \overline{33}\end{array}\right]$

Kenthur 3 nada ! - $6<$

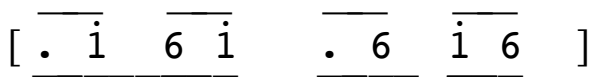

3. Angklung jinjing; nada $6-3<$

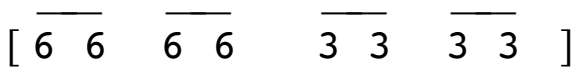

4. Angklung gantung;

Ompak/ intro Lagu Ayo Ngguyu laras pelog pathet nem :

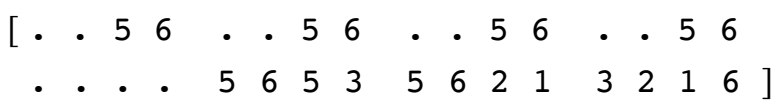

Lagu :

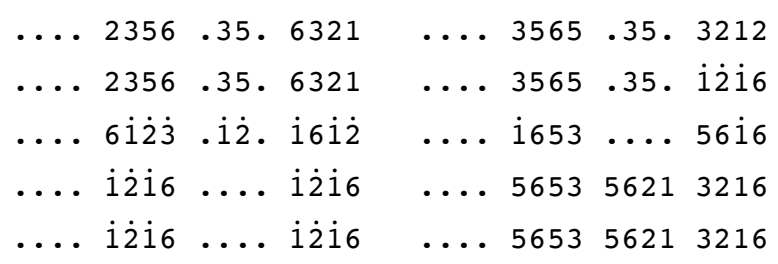

5. Calung

a. Gambang barung/ gambang penerus bagian ompak:

\begin{tabular}{|c|c|c|c|c|c|c|}
\hline . & $\overline{36}$ & $\overline{36}$ & $\overline{.6}$ & $\overline{i 6}$ & $\overline{52}$ & $\overline{32}(2)$ \\
\hline . & 36 & $\overline{36}$ & $\overline{.6}$ & $\overline{16}$ & $\overline{52}$ & $\overline{35}$ (5) \\
\hline .2 & 35 & 55 & 5 & .2 & 35 & 65 (5) \\
\hline 6 & $\overline{66}$ & 66 & 6 & & .2 & \\
\hline
\end{tabular}




\section{Abdi Seni Jurnal Pengabdian Kepada Masyarakat}

b. Bagian lagu

Gambang barung

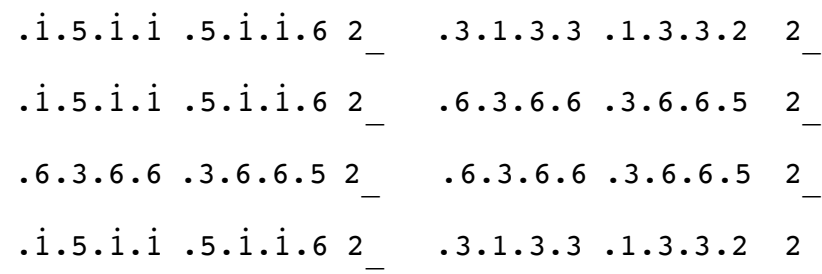

Gambang penerus

6.3 .6 .6 .3 .6 .6 .6 .2

$6.3 .6 .6 \cdot 3 \cdot 6 \cdot 6 \cdot 6 \cdot 2$

$5 \cdot 2 \cdot 5 \cdot 5 \cdot 2 \cdot 5 \cdot 5 \cdot 5 \cdot 2$

6.3 .6 .6 .3 .6 .6 .6 .2 penyusunan karya ini, dalam konsep "Reaktualisasi Gamelan Krumpyung”.

\section{KESIMPULAN}

Kegiatan PKM dosen perguruan tinggi adalah suatu keniscayaan yang telah menjadi tradisi untuk mendorong perkembangan seluruh aspek kehidupan di masyarakat. Program PKM adalah salah satu wujud kepedulian masyarakat akademisi dalam mengabdikan diri kepada masyarakat dengan tujuan agar terjadi sinergi antara perkembangan ilmu pengetahuan di kampus dengan kehidupan masyarakat di daerah. Aspek-aspek kehidupan yang terintegrasi dengan perkembangan ilmu pengetahuan di kampus telah terbukti kemanfaatannya sebagai pendorong daya hidup masyarakat, agar menjadi semakin maju sejalan dengan arus perkembangan zaman, termasuk aspek kehidupan masyarakat di bidang kesenian. ISI Surakarta yang secara spesifik mendorong sektor kehidupan di bidang kesenian, telah membuktikan prestasinya dengan turut serta membangun iklim pertumbuhan kesenian-kesenian daerah, hingga mampu berkembang selaras dengan pertumbuhan aspek kehidupan yang lain.

Kehidupan kesenian akan menjadi bermanfaat dan berdaya hidup bagi masyarakatnya jika kesenian tersebut mampu berinteraksi dan beradaptasi dengan lingkungannya. Kemampuan beradaptasi dalam kehidupan kesenian dapat menjadi persoalan yang serius jika tidak dikawal dan dikendalikan oleh orang yang benar-benar memiliki kompetensi di bidangnya. Kesenian selalu mengalami perkembangan, ia berjalan seiring dengan dinamika zaman. Saat ini di daerah-daerah telah banyak kesenian tradisi yang dikembangkan oleh para pelaku seni, namun sayangnya banyak pula yang cara mengembangkannya tidak dibekali ilmu pengetahuan yang cukup sehingga banyak yang kemudian berlawanan dengan norma-norma yang ada pada masyarakatnya. Tidak sedikit karya-karya seniman yang hanya berorientasi pada pemenuhan selera pasar, yang di dalam pengolahannya mengabaikan aspek-aspek mendasar yakni nilai estetik dan etik. 
Kehadiran ISI Surakarta melalui program PKM dosen menjadi sangat penting sebagai penyeimbang atas derasnya arus perkembangan kesenian-kesenian yang hidup di daerah yang semakin hari semakin dinamis. Eksistensi kesenian tradisi di daerah-daerah tampaknya jika diserahkan secara bebas kepada pelaku seni, tidaklah menunjukkan prestasi yang membanggakan, namun justru sebaliknya. Hal ini terbukti dengan maraknya penyajian kesenian musik tradisi di daerah yang didominasi oleh sajian "dangdut" dan "jaipong", yang terkesan dipaksakan untuk masuk dalam gamelan Jawa. Jika hal ini dibiarkan berlangsung tanpa diproteksi oleh seniman-seniman yang memiliki ilmu yang tepat, maka tidak mustahil jika kesenian-kesenian daerah akan kehilangan jati dirinya. Dengan demikian, peran perguruan tinggi senilah yang tepat untuk mengawal laju perkembangan kesenian-kesenian daerah agar keberadaannya tetap membawa nilai-nilai seni yang bermutu.

Kesenian daerah saat ini dalam kenyataan sudah banyak yang dirusak bahkan punah. Fenomena ini terjadi tidak lain akibat dari prilaku sebagian besar pekerja seni yang ada di daerahnya. Mereka dengan sadar atau tidak sadar telah melakukan segala upaya dengan berkesenian untuk memenuhi tuntutan hidupnya, dan banyak yang tidak mengacuhkan nilai-nilai budaya adiluhung. Ini sebagai bukti bahwa pelaku/ pekerja seni tidak lagi bisa diandalkan sebagai penjaga kesenian tradisinya. Tinggal satu kemungkinan yang bisa dipercaya mampu menjaga nilai-nilai budaya yang ada pada kesenian-kesenian daerah, yaitu melalui dunia pendidikan.

Jika kesenian harus berkembang sejalan dengan dinamika zaman, maka peran dunia pendidikan semakin penting. Guru-guru yang sebagian besar tidak memiliki kompetensi yang cukup, maka sudah seharusnya melakukan revolusi budaya. Sebagai pengabdi negara, seorang guru adalah tauladan masyarakat, tauladan bagi generasi penerus, yang selalu menjadi panutan dalam setiap langkah kehidupannya, termasuk juga kehidupan kesenian. Dengan demikian maka tidak ada cara lain kecuali melakukan peningkatan diri melalui pelatihan-pelatihan keterampilan yang terstruktur dan sistematis untuk mencapai tingkat kemampuan yang memadai sebagai tenaga pendidik yang profesional.

\section{Catatan Akhir}

${ }^{1}$ http://lektur.id, diakses tanggal 7 Oktober 2019.

\section{DAFTAR PUSTAKA}

Arends, Richard J. 2004. Learning to Teach. Boston, New York: McGraw-Hill Companies, Inc.

Depdiknas. 2003. Pola Pengembangan Kurikulum Berbasis Kompetensi, Program Studi pada LPTK-PTK Jenjang S-1. Jakarta: Dirjendikti Dep. Pemb. PTK dan Ketenagaan PT.

Doelle, Leslie L dan Lea Prasettio, 1986. Akustik Lingkungan. Erlangga, Jakarta.

Franz Magnis Suseno,1984.Etika Jawa: Sebuah Analisa Falsaû tentang

Kebijaksanaan HidupJawa. Jakarta: Gramedia.

Hall, Donald E, 1980. Musical Accoustics: An Introduction. Belmont, California.

I Wayan Sadra, 2002. "Eksplorasi Bunyi Gamelan Dalam Penciptaan Karya

Musik" Pembuatan Modul Kekaryaan KreatifMahasiswa.

I Wayan Sadra, 2005. Menimbang Pendekatan Pengkajian \& Penciptaan $\quad \mathrm{M} \mathrm{u} \mathrm{s} \mathrm{i} \mathrm{k}$ Nusantara. STSI Press

R. Mursid, 2013. Pengembangan Model Pengembangan praktek Berbasis Kompetensi Berorientasi Produksi. Universitas Negeri Medan

The Diagram Group, 1976. Musical Instruments of the World. Paddington Press, New York. 
White, Harvey E. and Donald H. White, 1980. Physics and Music: The Science of Musical Sound. Sounders College, Philadelphia.

Yusmanto CS, 2009, Calung Sebagai Identitas Kebuadayaan Banyumas, Kerjasama ISI Surakarta dengan LITBANG Banyumas

\section{Narasumber}

1. Kuncoro 59 tahun, Kepala Bidang Pendidikan dan Kebudayaan Kabupaten Purbalingga.

2. Sri Kustono 57 tahun. Sebagai guru seni dan Ketua MGMP Seni Budaya Kabupaten Purbalingga.

3. Sutomo 40 tahun, seniman dan ketua Sanggar Seni Dresnala Kabupaten Purbalingga.

4. Sulemi 61 tahun, seniman dan pimpinan kelompok Krumpyung.

5. Sri Rahayu, Desa Langgar, Kecamatan Kejobong, Kabupaten Purbalingga. 